\title{
44. THE RELATIONSHIP BETWEEN VARIATIONS IN ROCK-MAGNETIC PROPERTIES AND GRAIN SIZE OF SEDIMENTS FROM ODP HOLE 645C ${ }^{1}$
}

\author{
Frank R. Hall, ${ }^{2}$ William H. Busch, ${ }^{3}$ and John W. King ${ }^{2}$
}

\begin{abstract}
The potential use of anhysteretic remanence/magnetic susceptibility $(A R M / X)$ to indicate the relative grain-size variations of marine sediments is examined. Samples from Ocean Drilling Program (ODP) Hole 645C were measured for low-field magnetic susceptibility at two frequencies $(0.47$ and $4.7 \mathrm{kHz})$, given an anhysteretic remanence using a peak alternating magnetic (AC) field of $0.05 \mathrm{mT}$, and separated into the percentage sand, silt, and clay fractions. Results show little frequency dependence of low-field magnetic susceptibility and a direct relationship betweem $A R M / X$ and clay concentration.
\end{abstract}

\section{INTRODUCTION}

This paper seeks to determine if rapidly measured rock-magnetic parameters can be used as proxy indicators of changes in the size distribution of marine sediments. We refer to the size distribution of the magnetic fraction as the "particle-size" distribution, whereas the overall size distribution of both the magnetic and nonmagnetic fraction is described as the "grain-size" distribution.

King et al. (1982) demonstrated the utility of the ratio of anhysteretic remanence to magnetic susceptibility $(A R M / X)$ as an indicator of relative particle-size variations in magnetite. High (low) $A R M / X$ values indicate the presence of finer (coarser)grained magnetite particles. Magnetic minerals are subject to the same processes that transport and deposit nonmagnetic minerals, with the exception of environments where either in-situ deposition, e.g., by magnetotactic bacteria (Kirschvink and Chang, 1984; Petersen et al., 1986), or post-depositional dissolution by reduction diagenesis (Karlin and Levi, 1983, 1985; Canfield and Berner, 1987) are important processes. If in-situ deposition or reduction diagenesis are not important, and the magnetic minerals and nonmagnetic minerals have a similar size distribution in the source areas, then we hypothesize that variations in the relative particle size of magnetic minerals will reflect similar variations in grain size. King et al.'s results (1982) indicated that the $A R M / X$ technique should be useful for distinguishing variations in the proportion of fine to coarse material. Therefore, we would expect to see the largest variations of $A R M / X$ in sediments characterized by significant fluctuations in grain size.

Here, we report the results of an experiment comparing relative grain-size variations (percentages of sand, silt, and clay) with $A R M / X$ values obtained from samples from ODP Hole $645 \mathrm{C}$. We chose Hole $645 \mathrm{C}$ because (1) the dominant sedimentary processes are ice rafting and direct settling through the water column, (2) the source of the sediment is confined to the surrounding continental areas (Canada and Greenland), and (3) sedimentary sequences consist of alternating coarse-grained (sandy muds and muddy sands) with fine-grained (silty-muds and muddy silts) units. A relationship between these units and whole-core magnetic susceptibility has been established (Srivastava, Arthur,

\footnotetext{
${ }^{1}$ Srivastava, S. P., Arthur, M., Clement, B., et al. 1989. Proc. ODP, Sci. Results, 105: College Station, TX (Ocean Drilling Program).

2 Graduate School of Oceanography, Univ. of Rhode Island, Narragansett, RI 02882

${ }^{3}$ Dept. of Geology and Geophysics, Univ. of New Orleans, New Orleans, LA.
}

et al., 1987; Hall and King, this volume). Furthermore, neither in-situ production nor post-depositional diagenesis of magnetite are likely to be important processes in the sediments studied from Hole 645C.

Foraminiferal tests are important components of these sediments. The particle-size distribution of the magnetic component should reflect terrigenous influx. However, the sediments also have a high concentration of detrital $\mathrm{CaCO}_{3}$. Grain-size analyses include foraminiferal tests because their removal will alter the grain-size distribution of the terrigenous component. Magnetic mineral separations are now being performed on these samples to determine the composition and size distribution of the magnetic fraction.

\section{METHODS}

\section{Low-Field Magnetic Susceptibility and ARM}

Low-field magnetic susceptibility $(X)$ was measured using a Bartington Instruments dual-frequency susceptibility meter. We measured the samples at two frequencies: $0.47 \mathrm{kHz}$ (low frequency) and $4.7 \mathrm{kHz}$ (high frequency). The frequency dependence of susceptibility of these samples was calculated by the expression:

$$
X_{4.7} / X_{0.47} \text {. }
$$

Anhysteretic remanence was applied along the $y$-axis of the samples, using a peak alternating magnetic (AC) field of $100 \mathrm{mT}(1000 \mathrm{Oe})$ and a DC field of $0.05 \mathrm{mT}(0.5 \mathrm{Oe})$. Sample intensity was measured using an SCT three-axis cryogenic magnetometer.

\section{Grain Size}

Sand, silt, and clay percentages were determined gravimetrically for samples treated with neutralized, concentrated hydrogen peroxide to remove organic matter and rinsed with distilled water to remove salt. The sand fraction was isolated by wet-sieving, using a $62-\mu \mathrm{m}$ sieve. Silt and clay fractions were separated by centrifuging. During fractionation, the sediments were suspended in a sodium hexametaphosphate dispersant solution, which was rinsed from the samples before determining their weights. The sand, silt, and clay fractions were lyophilized to complete dryness before measuring weights.

\section{RESULTS}

Data from these analyses are given in Table 1. Low-field magnetic susceptibility and $A R M$ data can be found in Hall and King's Appendix (this volume). $A R M / X$ ratios were calculated using $X_{0.47}$.

Figure 1 indicates the downhole variation of the grain-size and rock-magnetic data. Areas of the graph represent percentages of sand, silt, and clay. There is little frequency dependence 
Table 1. $A R M$ and susceptibility data used in Figures 1 through 3.

\begin{tabular}{|c|c|c|c|c|c|c|}
\hline $\begin{array}{l}\text { Core, section, } \\
\text { interval }(\mathrm{cm})\end{array}$ & $\begin{array}{l}\text { Depth } \\
\text { (mbsf) }\end{array}$ & $\begin{array}{l}\text { Sand } \\
(\%)\end{array}$ & $\begin{array}{l}\text { Silt } \\
(\%)\end{array}$ & $\begin{array}{l}\text { Clay } \\
(\%)\end{array}$ & $A R M / X$ & $\begin{array}{l}\text { Hf/Lf } \\
\text { susc. }\end{array}$ \\
\hline $105-645 \mathrm{C}-1 \mathrm{H}-1,12$ & 0.12 & 6.4 & 32.5 & 61.1 & 11.98 & 1.00 \\
\hline $1 \mathrm{H}-1,20$ & 0.20 & 5.8 & 33.3 & 60.9 & 8.70 & 0.99 \\
\hline $1 \mathrm{H}-1,30$ & 0.30 & 19.0 & 37.8 & 43,2 & 4.12 & 0.99 \\
\hline $1 \mathrm{H}-1,40$ & 0.40 & 46.7 & 31.3 & 22.1 & 1.80 & 0.99 \\
\hline $1 \mathrm{H}-1,50$ & 0.50 & 35.9 & 38.5 & 25.7 & 1.44 & 0.99 \\
\hline $1 \mathrm{H}-1,60$ & 0.60 & 32.1 & 42.5 & 25.5 & 0.74 & 1.01 \\
\hline $1 \mathrm{H}-1,70$ & 0.70 & 43.4 & 31.1 & 25.6 & 2.56 & 0.99 \\
\hline $1 \mathrm{H}-1,80$ & 0.80 & 12.0 & 37.7 & 50.3 & 5.27 & 0.99 \\
\hline $1 \mathrm{H}-1,90$ & 0.90 & 31.5 & 40.0 & 28.4 & 2.19 & 1.00 \\
\hline $1 \mathrm{H}-1,100$ & 1.00 & 17.1 & 33.5 & 49.4 & 5.55 & 0.99 \\
\hline $1 \mathrm{H}-1,110$ & 1.10 & 0.4 & 28.8 & 70.8 & 9.01 & 0.97 \\
\hline $1 \mathrm{H}-1,120$ & 1.20 & 30.2 & 19.2 & 50.6 & 5.32 & 0.98 \\
\hline $1 \mathrm{H}-1,148$ & 1.48 & 29.5 & 29.6 & 40.9 & 1.90 & 1.00 \\
\hline $1 \mathrm{H}-2,10$ & 1.60 & 46.5 & 31.4 & 22.1 & 2.13 & 1.00 \\
\hline $1 \mathrm{H}-2,20$ & 1.70 & 22.3 & 29.3 & 48.4 & 4.44 & 0.98 \\
\hline $1 \mathrm{H}-2,31$ & 1.81 & 16.4 & 38.1 & 45.6 & 3.17 & 0.99 \\
\hline $1 \mathrm{H}-2,40$ & 1.90 & 16.6 & 43.6 & 39.8 & 2.44 & 0.99 \\
\hline $1 \mathrm{H}-2,60$ & 2.10 & 28.4 & 40.4 & 31.2 & 2.13 & 0.99 \\
\hline $1 \mathrm{H}-2,70$ & 2.20 & $17-9$ & 43.5 & 38.6 & 1.80 & 0.98 \\
\hline $1 \mathrm{H}-2,80$ & 2.30 & 30.1 & 39.9 & 30.0 & 1.93 & 0.99 \\
\hline $1 \mathrm{H}-2,90$ & 2.40 & 33.7 & 39.4 & 27.0 & 2.00 & 0.99 \\
\hline $1 \mathrm{H}-2,100$ & 2.50 & 36.1 & 37.2 & 26.7 & 2.00 & 0.99 \\
\hline $1 \mathrm{H}-2,120$ & 2.70 & 40.2 & 35.7 & 24.2 & 2.33 & 0.99 \\
\hline $1 \mathrm{H}-2,130$ & 2.80 & 38.2 & 32.3 & 29.5 & 2.09 & 0.99 \\
\hline $1 \mathrm{H}-3,2$ & 3.02 & 38.8 & 33.2 & 28.0 & 2.03 & 0.99 \\
\hline $1 \mathrm{H}-3,10$ & 3.10 & 33.0 & 35.2 & 31.8 & 2.55 & 0.99 \\
\hline $1 \mathrm{H}-3,20$ & 3.20 & 31.2 & 37.7 & 31.2 & 3.19 & 1.00 \\
\hline $1 \mathrm{H}-3,30$ & 3.30 & 30.8 & 38.0 & 31.2 & 3.02 & 1.00 \\
\hline $1 \mathrm{H}-3,40$ & 3.40 & 27.6 & 38.9 & 33.5 & 3.00 & 0.98 \\
\hline $1 \mathrm{H}-3,50$ & 3.50 & 32.7 & 40.2 & 27.1 & 2.70 & 0.99 \\
\hline $1 \mathrm{H}-3,80$ & 3.80 & 30.1 & 40.6 & 29.3 & 2.80 & 0.99 \\
\hline $1 \mathrm{H}-3,90$ & 3.90 & 40.6 & 34.1 & 25.3 & 2.80 & 1.00 \\
\hline $1 \mathrm{H}-3,100$ & 4.00 & 4.6 & 42.9 & 52.5 & 4.03 & 0.98 \\
\hline $1 \mathrm{H}-3,110$ & 4.10 & 10.5 & 39.4 & 50.1 & 4.60 & 0.99 \\
\hline $1 \mathrm{H}-3,130$ & 4.30 & 39.6 & 35.3 & 25.2 & 1.57 & 1.00 \\
\hline $3 \mathrm{H}-1,0$ & 14.00 & 34.7 & 37.5 & 27.8 & 2.14 & 0.99 \\
\hline $3 \mathrm{H}-1,10$ & 14.10 & 33.1 & 37.9 & 29.0 & 3.50 & 0.99 \\
\hline $3 \mathrm{H}-1,20$ & 14.20 & 33.3 & 36.9 & 29.9 & 2.75 & 1.00 \\
\hline $3 \mathrm{H}-1,30$ & 14.30 & 29.9 & 37.4 & 32.7 & 4.13 & 1.00 \\
\hline $3 \mathrm{H}-1,50$ & 14.50 & 26.7 & 40.5 & 32.8 & 3.51 & 0.98 \\
\hline $3 \mathrm{H}-1,60$ & 14.60 & 17.7 & 41.0 & 41.4 & 3.54 & 0.97 \\
\hline $3 \mathrm{H}-1,70$ & 14.70 & 24.7 & 43.4 & 31.9 & 2.94 & 0.99 \\
\hline $3 \mathrm{H}-1,83$ & 14.83 & 40.9 & 34.5 & 24.7 & 2.43 & 1.00 \\
\hline $3 \mathrm{H}-1,90$ & 14.90 & 29.9 & 39.4 & 30.8 & 2.84 & 1.00 \\
\hline $3 \mathrm{H}-1,100$ & 15.00 & 26.3 & 39.9 & 33.8 & 2.88 & 0.99 \\
\hline $3 \mathrm{H}-1,110$ & 15.10 & 30.0 & 34.3 & 35.7 & 4.66 & 1.00 \\
\hline $3 \mathrm{H}-1,120$ & 15.20 & 11.3 & 34.1 & 54.6 & 5.08 & 0.98 \\
\hline $3 \mathrm{H}-1,130$ & 15.30 & 46.9 & 21.4 & 31.7 & 4.29 & 0.98 \\
\hline $3 \mathrm{H}-1,140$ & 15.40 & 28.5 & 43.7 & 27.8 & 2.31 & 0.99 \\
\hline $3 \mathrm{H}-2,0$ & 15.50 & 22.1 & 43.2 & 34.7 & 3.22 & 1.00 \\
\hline $3 \mathrm{H}-2,10$ & 15.60 & 29.1 & 42.1 & 28.8 & 3.15 & 1.00 \\
\hline $3 \mathrm{H}-2,20$ & 15.70 & 22.9 & 41.5 & 35.7 & 4.27 & 0.97 \\
\hline $3 \mathrm{H}-2,40$ & 15.90 & 13.5 & 51.1 & 35.4 & 2.34 & 0.98 \\
\hline $3 \mathrm{H}-2,50$ & 16.00 & 17.7 & 45.2 & 37.1 & 5.83 & 0.99 \\
\hline $3 \mathrm{H}-2,60$ & 16.10 & 29.2 & 34.6 & 36.3 & 3.01 & 0.99 \\
\hline $3 \mathrm{H}-2,70$ & 16.20 & 19.8 & 48.9 & 31.3 & 3.15 & 0.99 \\
\hline $3 \mathrm{H}-2,80$ & 16.30 & 23.8 & 44.2 & 32.0 & 2.63 & 0.99 \\
\hline $3 \mathrm{H}-2,90$ & 16.40 & 26.1 & 45.0 & 28.9 & 2.08 & 0.99 \\
\hline $3 \mathrm{H}-2,102$ & 16.52 & 28.1 & 43.1 & 28.9 & 2.20 & 0.99 \\
\hline $3 \mathrm{H}-2,120$ & 16.70 & 25.1 & 40.0 & 34.9 & 3.37 & 0.99 \\
\hline $3 \mathrm{H}-3,44$ & 17.44 & 15.4 & 33.2 & 51.3 & 3.10 & 0.99 \\
\hline $3 \mathrm{H}-3,54$ & 17.54 & 37.8 & 26.3 & 35.9 & 2.04 & 0.98 \\
\hline $3 \mathrm{H}-3,64$ & 17.64 & 5.4 & 43.1 & 51.5 & 5.23 & 0.98 \\
\hline $3 \mathrm{H}-3,71$ & 17.71 & 28.6 & 41.7 & 29.7 & 1.94 & 0.99 \\
\hline $3 \mathrm{H}-3,94$ & 17.94 & 23.7 & 44.4 & 31.9 & 2.05 & 0.99 \\
\hline $3 \mathrm{H}-3,101$ & 18.01 & 22.6 & 47.1 & 30.3 & 1.94 & 0.99 \\
\hline $3 \mathrm{H}-3,105$ & 18.05 & 9.4 & 39.3 & 51.3 & 3.54 & 0.98 \\
\hline $3 \mathrm{H}-3,124$ & 18.24 & 31.4 & 27.1 & 41.5 & 2.19 & 0.99 \\
\hline $3 \mathrm{H}-3,14 \mathrm{I}$ & 18.41 & 33.5 & 26.1 & 40.5 & 1.86 & 0.99 \\
\hline $3 \mathrm{H}-4,25$ & 18.75 & 37.1 & 26.1 & 36.9 & 1.70 & 1.00 \\
\hline $3 \mathrm{H}-4,41$ & 18.91 & 16.6 & 31.0 & 52.5 & 3.65 & 0.98 \\
\hline $3 \mathrm{H}-5,16$ & 20.16 & 15.3 & 38.4 & 46.4 & 3.89 & 0.98 \\
\hline $3 \mathrm{H}-5,24$ & 20.24 & 19.4 & 49.2 & 31.5 & 1.90 & 1.00 \\
\hline $3 \mathrm{H}-5,35$ & 20.35 & 23.5 & 46.3 & 30.3 & 1.66 & 0.99 \\
\hline $3 \mathrm{H}-5,44$ & 20.44 & 27.7 & 44.1 & 28.2 & 1.53 & 1.00 \\
\hline $3 \mathrm{H}-5,73$ & 20.73 & 32.9 & 40.5 & 26.7 & 1.66 & 1.00 \\
\hline $3 \mathrm{H}-5,82$ & 20.82 & 26.3 & 39.7 & 33.9 & 3.41 & 0.99 \\
\hline $3 \mathrm{H}-5,97$ & 20.97 & 30.9 & 38.0 & 31.1 & 2.79 & 0.99 \\
\hline
\end{tabular}

Note: The values for $A R M$ and susceptibility can be found in Hall and King (this volume). of low-field susceptibility. The lack of frequency dependence of susceptibility indicates that super-paramagnetic particles are not common for sediments from Hole $645 \mathrm{C}$. The rarity of superparamagnetic particles increases the validity of the $A R M / X$ ratio for indicating relative particle size (King et al., 1982; Bloemendal et al., 1985). The results in Figure 2 indicate that $A R M / X$ variations are strongly positively correlated with clay concentration.

Figure 3 shows the correlation between clay content and $A R M / X$. Clay content is expressed as the percentage of clay (Fig. 3A) and the ratio of the percentage of clay to the sand and percentage of silt (\%clay/[\% sand $+\%$ silt $]$; Fig. 3B). The $\%$ clay $/(\%$ sand $+\%$ silt $)$ ratio is used as a measure of the proportion of fine- to coarse-grained sediments. Both measures of clay content correlate highly with $A R M / X$. Correlation coefficients are 0.7698 for $\%$ clay, and 0.8057 for $\%$ clay/(\% silt + $\%$ sand). Correlation coefficients were determined using a Texas Instruments TI-59 programmable calculator.

\section{CONCLUSIONS}

From these results, we conclude as follows:

1. There is little frequency dependence of susceptibility in our samples, suggesting that super-paramagnetic grains are not common for sediments from Hole $645 \mathrm{C}$, which increases the validity of the $A R M / X$ ratio as an indicator of relative particle size.

2. The $A R M / X$ ratio is a useful indicator of variations in clay content.

\section{ACKNOWLEDGMENTS}

This project was funded by JOI USSAC POs 76322 and 1892-B05.

\section{REFERENCES}

Bloemendal, J., Barton, C. E., and Radhakrishnamurthy, C., 1985. Correlation between Rayleigh loops and frequency-dependent and quadrature susceptibility: application to magnetic granulometry of rocks. J. Geophys. Res., 90:8789-8792.

Canfield, D.E., and Berner, R. A., 1987. Dissolution and pyritization of magnetite in anoxic marine sediments. Geochemica Cosmochimica Acta, 51:645-659.

Karlin, R., and Levi, S., 1985 Geochemical and sedimentological control of magnetic properties of hemipelagic sediments. J. Geophys. Res., 90:373-392.

King, J., Banerjee, S. K., Marvin, J., and Ozdemir, O., 1982. A comparison of different magnetic methods for determining the relative grain size in natural materials: some results from lake sediments. Earth Planet. Sci. Lett., 59:404-419.

Kirschvink, J. L., and Chang, S.-B. R., 1984. Ultrafine-grained magnetite in deep-sea sediments: possible bacterial microfossils. Geology, 12:559-562.

Petersen, N., von Dobeneck, T., and Vali, H., 1986. Fossil bacterial magnetite in deep-sea sediments from the South Atlantic Ocean. Nature, 320:611-615.

Srivastava, S., Arthur, M., et al., 1987. Proc. ODP, Init. Repts., 105: College Station, TX (Ocean Drilling Program).

Date of initial receipt: 14 September 1987

Date of acceptance: 21 October 1988

Ms 105B-149 

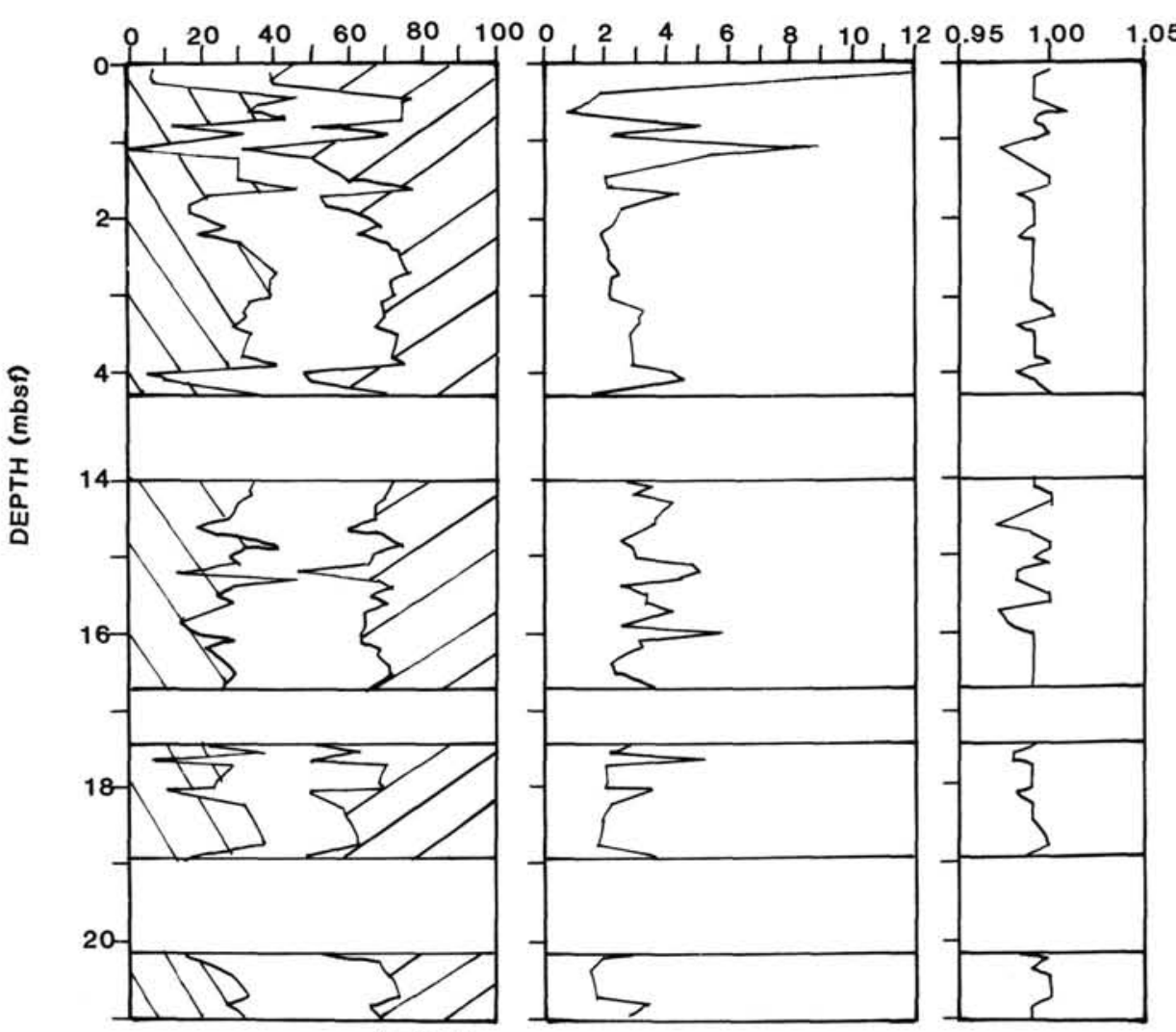

\% SAND

\% SILT

\% CLAY

Figure 1. Depth vs. percentage of sand, silt, and clay, $A R M / X$, and $\mathrm{X}_{0.47} / \mathrm{X}_{4,7}$. The area beneath the curves represents the percentages of sand, silt, and clay. $A R M / X$ values follow the trend of the percentage of clay. There is no apparent frequency dependence of susceptibility, which indicates that superparamagnetic particles are not abundant. 
F. R. HALL, W. H. BUSCH, J. W. KING

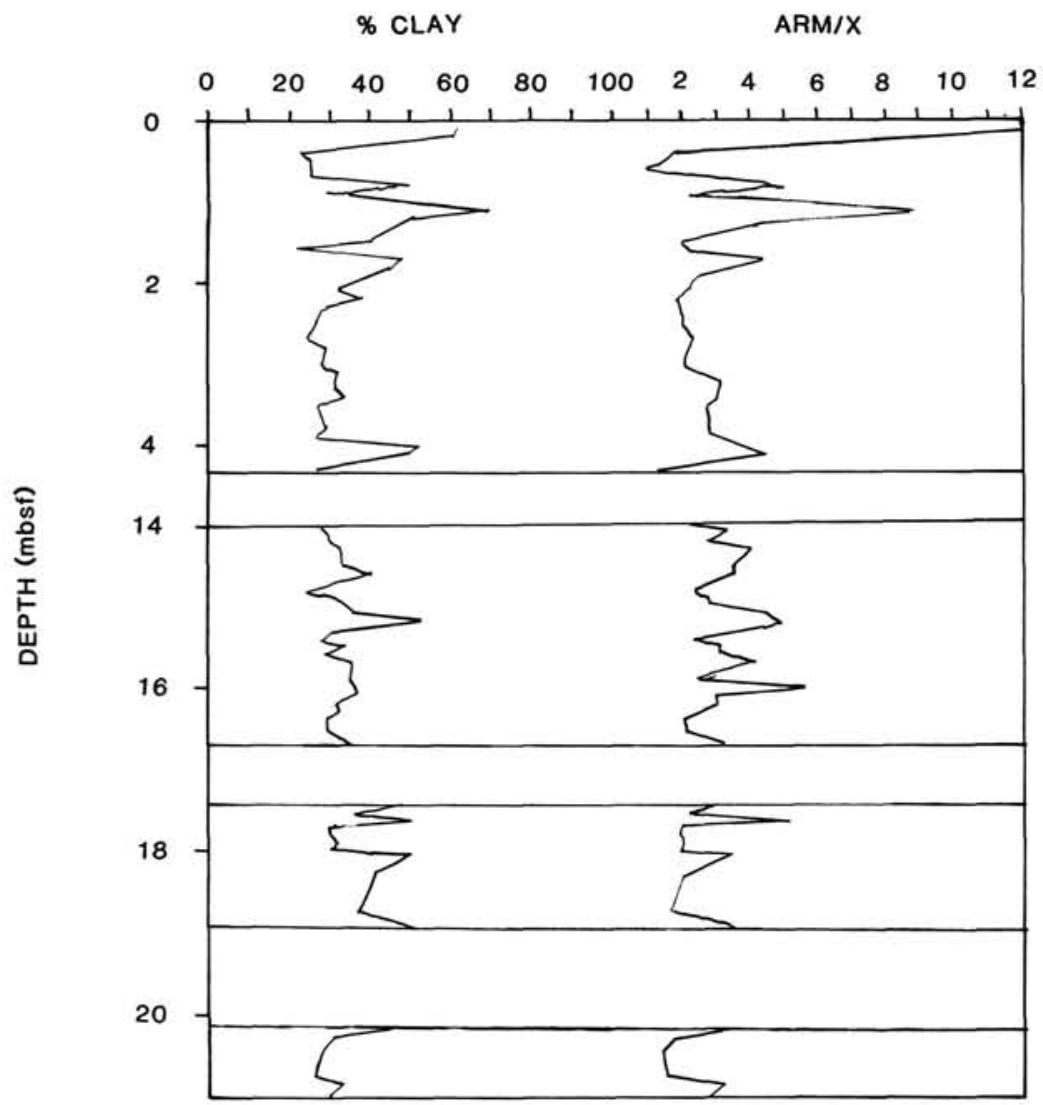

Figure 2. $A R M / X$ and percentage of clay vs. depth, showing that $A R M / X$ is positively correlated with variations in the percentage of clay downhole. 

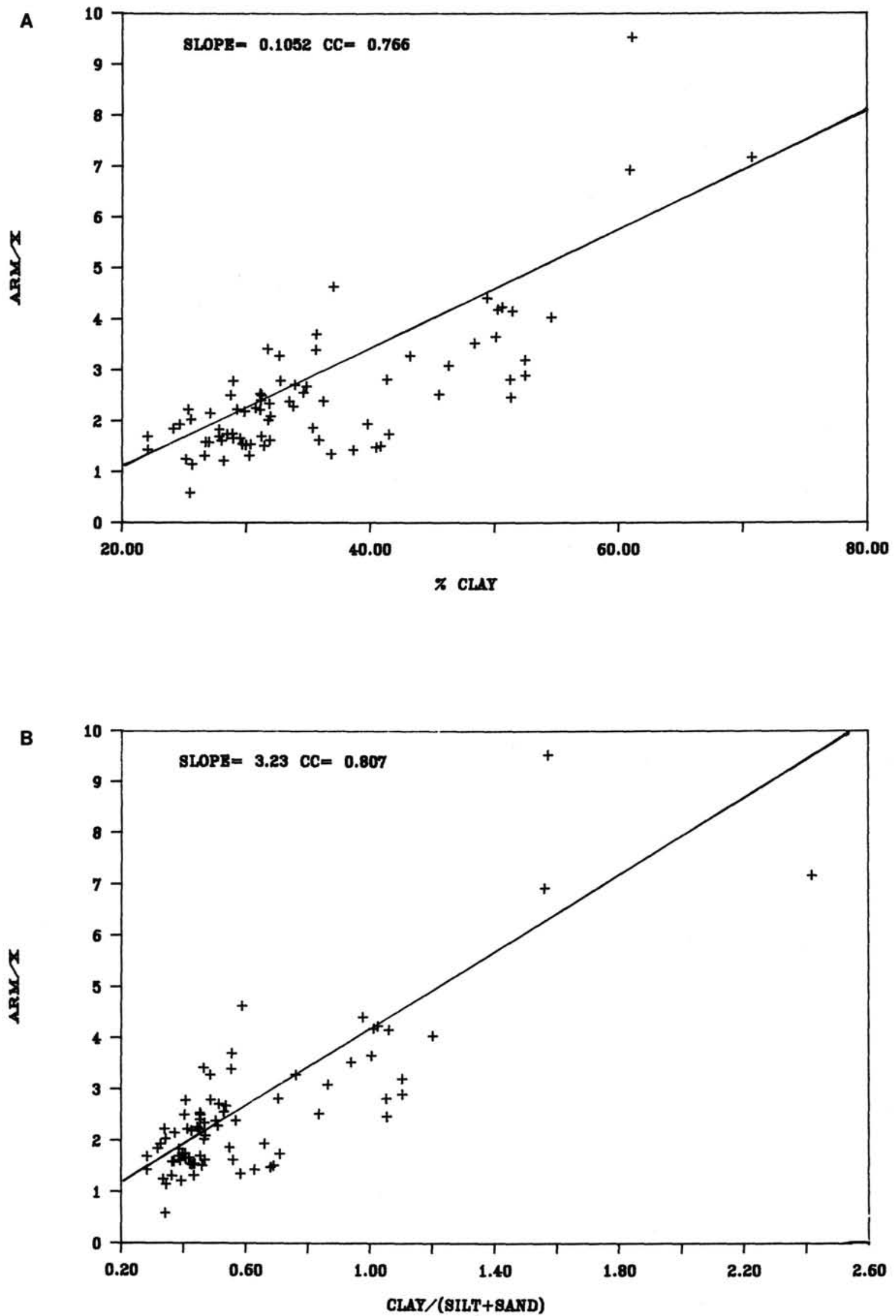

Figure 3. $A R M / X$ vs. clay content, showing an apparent linear trend between $A R M / X$ and clay content in Hole $645 C$. A. $A R M / X$ in terms of percentage of clay. B. $A R M / X$ in terms of percentages of clay/(sand + silt). Correlation coefficients also are plotted. 